\title{
La construcción de la bóveda de arista rectangular en el tratado de Gelabert: teoría y práctica
}

\author{
The construction of the rectangular groin vault \\ in Gelabert's treatise: theory and practice
}

$\underline{\text { R. Senent-Domínguez }}^{(*)}$, C. Pérez-de-los-Ríos ${ }^{(*)}$

\section{RESUMEN}

Entre los tipos de bóvedas más habituales del renacimiento español está la bóveda de arista, concebida para cubrir recintos cuadrados. Cuando la bóveda de arista se dispone sobre una planta rectangular, es necesario que el sistema de abovedamiento se adapte a esta nueva situación, lo que multiplica los problemas, dando lugar a diversas soluciones constructivas. Este artículo analiza el modelo teórico de bóveda de arista rectangular propuesto por los tratados de cantería de los siglos XVI-XVIII, centrándose en el manuscrito del mallorquín Joseph Gelabert (s. XVII), y su relación con bóvedas de este tipo construidas en la ciudad de Palma de Mallorca entre los siglos XVIXVIII.

Se presta especial atención al problema de la labra de las dovelas de la arista por medio de plantillas y su relación con el "problema del ángulo sólido", aportando nuevos datos sobre un dibujo del manuscrito de Hernán Ruiz el Joven (s.XVI).

$970-10$

Palabras clave: Bóveda de arista; manuscritos y tratados de cantería; Joseph Gelabert; Palma de Mallorca; siglos XVI, XVII y XVIII.

\section{SUMMARY}

The groin vault is one of the most common types of vaults in Spain, designed to cover square spaces. When the groin vault is arranged on a rectangular plan, the vaulting system must be adapted to the new situation. This new arrangement multiplies the problems, entailing in different constructive solutions.

This paper analyzes the theoretical model of the rectangular groin vault as proposed in stonecutting treatises (16th-18th centuries), focusing on the manuscript by Joseph Gelabert (17th century), and its relationship with vaults built in Palma de Mallorca from the 16th to the 18th century.

Special attention is paid to the carving of the pieces of the groins by means of templates and their relationship to the "problem of the solid angle", providing new data on a drawing in the manuscript of Hernán Ruiz the Younger (16th century).

Keywords: Groin vault; stonecutting manuscripts and treatises; Joseph Gelabert; Palma de Mallorca; 16th, 17th and 18th centuries. 


\section{INTRODUCCIÓN. EL PROBLEMA DE LA BÓVEDA DE ARISTA SOBRE PLANTA RECTANGULAR}

El manuscrito de cantería de Alonso de Vandelvira agrupa las bóvedas de arista y baída bajo el denominador común de "capillas cuadradas", ya que ambas están concebidas para cubrir recintos de planta cuadrada, aunque responden a criterios formales distintos; mientras que la bóveda baída se construye a partir de una forma esférica, la bóveda de arista basa su construcción en la bóveda de cañón, es decir, en el cilindro. Cuando la planta se alarga en una dirección generando un recinto rectangular, es necesario que el sistema de abovedamiento se adapte a esta nueva situación, lo que dará lugar a diversas soluciones constructivas.

Para que dos bóvedas de cañón den lugar a una de arista de planta cuadrada ambas deben tener el mismo radio, sus arranques deben estar situados al mismo nivel y sus ejes deben cortarse perpendicularmente sobre el mismo plano horizontal. La bóveda resultante está compuesta de cuatro tramos de cañón unidos según las aristas salientes de la intersección. Estos cuatro tramos no ofrecen especial complicación y la dificultad de la bóveda de arista se centra en determinar las dos curvas de intersección que describen las aristas.

1. Dos posibles soluciones para la bóveda de arista de planta rectangular: arco mayor rebajado y arco menor peraltado, y alternativa como intersección de cilindros o "arco avanzado en cercha".

1. Two feasible solutions for the rectangular groin vault: lowering the wider arch and raising the narrower arch, with the alternative solution being the intersection of two cylinders or "Welsh groins".
Estas curvas se determinan por puntos, llevando las hiladas sobre la diagonal e igualando alturas. Para dibujar dichas curvas Vandelvira recomienda unir los puntos "adulciendo los puntos con el compás de tres en tres puntos" (1, Fol. 18v).

Si la bóveda de arista se dispone sobre una planta rectangular las dos bóvedas salvan distinta luz y es necesario que una de las bóvedas de cañón cambie su directriz para igualar su altura con la otra bóveda peraltándose o rebajándose según el caso. Esta adaptación no es automática ni las soluciones que se obtienen únicas; algunos ejemplos se muestran en la Figura 1. Tal y como señala Fray Lorenzo de San Nicolás "aunque también confieso haber visto estas capillas por arista prolongadas, muy buenos maestros bien atados por la dificultad de sus cortes" (2, Fol. 101v).

La solución más frecuente en los tratados es rebajar la bóveda de mayor luz, Ilevando las hiladas del lado menor sobre la diagonal y sobre el lado mayor e igualando alturas (Figura 2). Tan sólo Derand dibuja el arco de menor luz peraltado, para igualar su altura con la del mayor (3), ver Figura 3.

\section{INTRODUCTION. THE PROBLEM OF THE RECTANGULAR GROIN VAULT}

In Alonso de Vandelvira's stonecutting manuscript the groin vault and the sail vault fall into the category "square chapels", because they were both intended to cover a square plan, even though they correspond to different formal criteria: whereas the sail vault comes from the semi-sphere, the groin vault construction is based on the barrel vault, that is to say, the semi-cylinder. When the perimeter stretches to generate a rectangular plan, the vaulting system must be adapted to this new situation; this adjustment will lead to several constructive solutions.

A square groin vault is caused by the intersection of two barrel vault (semicylinders), which must meet certain conditions: both vaults must have the same radius, with their springings placed at the same level and their axis cut perpendicularly on the same horizontal plane. The resulting vault consists of four barrel vault sections joined by the projecting edges (groins) of the intersection. These four sections pose no particular problem and the difficulty of the vault is concentrated in the determination of the curves describing the groins.

The outline of the groins is obtained by means of ordinates, taking the courses to the diagonal while equaling its heights. To draw these curves Vandelvira recommends connecting the points "by smoothing every three points with the compass" (1, Fol. 18v).

When the groin vault covers a rectangular plan, the two barrel vaults have different spans and the profile of one of the vaults must be changed in order to equal the height of both vaults, lowering or raising the profile of one vault as appropriate. This adaptation is not automatic and the obtained solutions are not unique; some examples are shown in Figure 1. As Fray Lorenzo de San Nicolás said: "I confess to have seen very good masons bonded by the complexity of these stretched groin vaults".

In treatises, the usual solution is to lower the wider vault by ordinates, taking the courses of the narrower vault to the diagonal and to the wider side, and equaling its heights (Figure 2). Derand is the only author who raises the narrower arch, equaling its height with the wider arch (3), see Figure 3. 


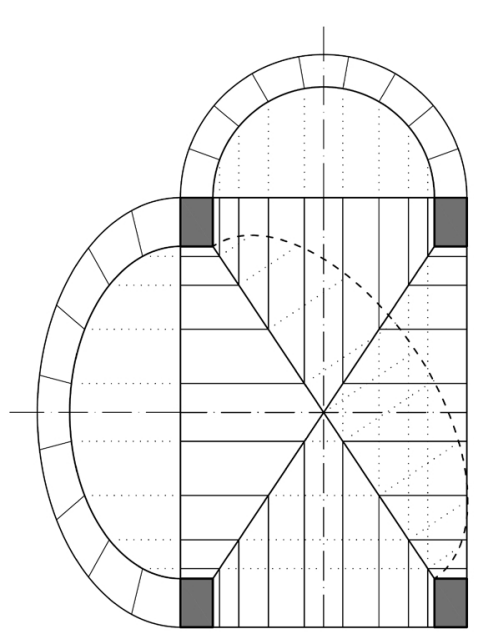

\section{EL MODELO TEÓRICO: LA BÓVEDA DE ARISTA SOBRE PLANTA RECTANGULAR EN EL MANUSCRITO DE GELABERT}

El manuscrito de cantería del mallorquín Joseph Gelabert (1653) representa una excepción a la bóveda de arista rectangular habitual en los tratados. Es quién más profusamente desarrolla el tema, proponiendo cuatro soluciones distintas: tres con arcos escarzanos (Trazas 43, 44 y 45) y una con arcos carpaneles (ovales, Traza 46) (4, Fols. 55v, 56v, 57v y 58v). Además sus soluciones se apartan de las de las de otros autores, siendo el único que trabaja con bóvedas rebajadas y siendo también el único que contempla la posibilidad de que la arista se curve en planta, es decir, que sea una curva alabeada.

Recientemente Enrique Rabasa ha publicado una edición crítica del manuscrito, donde se explican cada una de las construcciones, por lo que el análisis aquí recogido se limita a señalar los puntos característicos de cada una de ellas de cara a su comparación con casos construidos (5, pp. 144-154).

Los trazados de Gelabert comienzan siempre con la planta rectangular y el dibujo del arco escarzano correspondiente al lado mayor; ${ }^{1}$ fijados los arranques y la altura de la clave, el trazado del arco de circunferencia es relativamente sencillo.

En el primer trazado (Traza 43), el proceso es similar al que encontramos en el resto de tratados: las aristas recorren las diagonales de la planta y el arco correspondiente al lado menor es una curva trazada por puntos de curvatura variable (Figura 4a). En el segundo (Traza 44) y tercer trazado (Traza 45), el arco correspondiente al lado menor es un arco de circunferencia resultado de

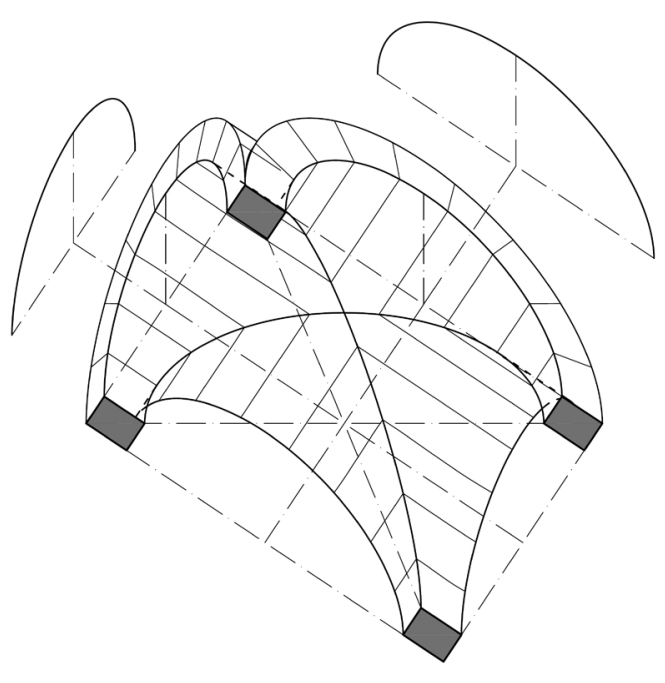

\section{THE THEORETICAL MODEL: THE RECTANGULAR GROIN VAULT IN GELABERT'S MANUSCRIPT}

The stonecutting manuscript by the Majorcan architect Joseph Gelabert (1653) represents an exception to the rectangular groin vault as commonly described in treatises. This treatise richly develops the problem, proposing four different solutions: three with segmental arches (Designs 43, 44 and 45) and another one with threecentered arches (Design 46) (4, Fols. 55v, $56 v, 57 v$ and $58 v$ ). These solutions deviate from those proposed by other authors, being the only treatise working with lowered vaults and the only one where the horizontal projection of the groins waves (with warped groins).

Enrique Rabasa has recently published a scholarship edition of the manuscript where he explains each construction in detail. Therefore our analysis merely states the significant characteristics of each construction in order to compare with the built examples (5, pp 144-145).

Gelaberts designs always begin with the rectangular plan and a segmental arch over the larger span; ${ }^{I}$ when the springing and the sagitta of the arch (position of the keystone) are set, the outline of the arch is easily found.

In the first construction (Design 43) the procedure is similar to that found in other treatises: the groins are placed over the diagonals of the plan while the arch over the smaller span is a curve determined by points with variable curvature (Figure 4a). In the second (Design 44) and third (Design 45) constructions, the arch over the smaller span is a circular arc with the same sagitta
2. Trazado habitual de la bóveda de arista rectangular, con el arco mayor rebajado.

2. Usual design of the rectangular groin vault, lowering the larger arc.

3. Bóvedas rectangulares de la iglesia de Saint-Paul de París (1627-1641), obra de Martellange y Derand.

3. Rectangular groin vaults in Saint-Paul's church in Paris (1627. 1641), by Derand and Martellange.

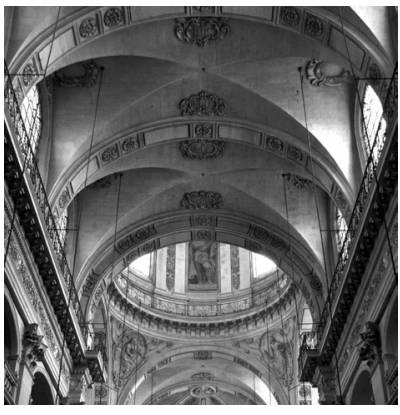

${ }^{1}$ La construcción consiste en determinar el centro de una circunferencia conocidos tres puntos, que describen algunos tratados. Gelabert, tal y como ha señalado Rabasa $(5$, p. 36 , nota 19 y p. 404, nota 526), desconoce la construcción correcta por lo que lo hace por tanteo.

1 This construction finds the center of a circumference where three points are given, described by some treatises. As Rabasa has noted (5, p. 36 , footnote 19, and p. 405, footnote 526), Gelabert didn't know the accurate construction, making it by trial and error. 
igualar su altura en la clave con la altura del arco mayor y trazar una circunferencia que pasa por tres puntos (Figuras $4 b$ y $4 c$ respectivamente). De este modo, los arcos que delimitan la bóveda son arcos de circunferencia de distinto radio, cuyos centros están situados a distinta altura.

En el segundo trazado, una vez superado el enjarje, ambos arcos se dividen en un número igual de partes iguales. La arista en planta es una curva que resulta de unir los puntos de intersección de las hiladas que vienen desde uno y otro arco, paralelas al perímetro, la arista es por tanto una curva alabeada. Considerando la superficie de intradós de la bóveda de arista, al menos una de las dos bóvedas de cañón no puede tener las hiladas horizontales, de hecho Gelabert señala que "las hiladas del lado estrecho no se encuentran todas perfectamente a nivel, como las del lado ancho" (5, p. 148); es decir, no se trata de un cilindro sino de un cilindroide, formado por rectas contenidas en planos verticales paralelos y que se apoyan sobre dos curvas: el arco del perímetro y la arista alabeada (Figura 4b).

Gelabert no está conforme con estos dos trazados y propone uno de su invención en el que, una vez dividido el arco mayor en un número de partes iguales, se busca sobre el arco menor, para cada hilada, el punto situado a la misma altura. De nuevo la arista es una curva alabeada que se obtiene uniendo los puntos de intersección de las hiladas. A diferencia de la solución anterior, las hiladas son horizontales pero las anchuras de las dovelas en la bóveda menor no son constantes; estamos ante la intersección de dos cilindros de revolución de distinto radio y cuyos centros no están situados a la misma altura (Figura 4c).

Por último Gelabert propone una cuarta bóveda de arista de planta rectangular rebajada (Traza 46), construida por medio de arcos carpanel (arcos ovales de tres centros), que también es invención suya. Para esta bóveda el método empleado es similar al anterior, igualando alturas; la diferencia radica en los arranques, construidos con una curvatura distinta.

\section{EL MODELO CONSTRUIDO: BÓVEDAS DE ARISTA SOBRE PLANTA RECTANGULAR EN PALMA DE MALLORCA (SIGLOS XVII Y XVIII)}

En la ciudad de Palma de Mallorca encontramos varias bóvedas de arista de planta rectangular emparentadas con las soluciones descritas por Gelabert en su manuscrito; no sólo son bóvedas de planta rectangular rebajadas, sino que en muchas as the larger arch; the problem is limited only by the drawing of a circumference where three points are given (Figures. $4 b$ and $4 \mathrm{C}$ respectively). Thus, the perimeter arches of the vault are circular arcs with different radii with their centers located at different heights.

In the second construction, once the tasde-charge is overtaken, both arches are divided into an equal number of equal parts. The horizontal projection of the groin is a curve obtained by joining the points of the intersection of the courses coming from each arch parallel to the perimeter; therefore, the groin is a space curve (warped groin). Considering the intrados surface of the vault, at least one of the barrel vaults can't have horizontal courses. Indeed, Gelabert notes that "the courses of the narrow side are not perfectly horizontal, where those in the larger side are" $(5, p .148)$; that is to say, the vault is not a cylinder but a cylindroid, composed of straight lines in parallel vertical planes which rely on two curves: the perimeter arch and the warped groin (Figure 4b).

Gelabert is not satisfied with these two constructions and proposes one of his own invention: once the wider arch has been divided in an number of equal parts, he searches for each course on the narrower arch, the point placed at the same height. Once again the groin is a space curve joining the points of intersection of the courses. In contrast to the previous construction, the courses are horizontal but the widths of the courses in the narrower vault are not equal; this construction involves the intersection of two horizontal cylinders with different radii, whose axis are not placed at the same height (Figure 4c).

Finally Gelabert proposes a fourth lowered rectangular groin vault (Design 46), drawn with three-centered arches (oval arches), which is also his own invention. The procedure is similar to the previous vault, equaling the height of the courses; the differences lie in the springings of the vaults, outlined with a different curvature from the central section of the vault.

\section{THE BUILT MODEL: RECTANGULAR GROIN VAULTS IN PALMA (17th AND 18th CENTURIES)}

In the city of Palma (Majorca) we find several rectangular groin vaults related to those described by Gelabert's manuscript; not only the vaults are lowered rectangular groin vaults, but also many of them have a clearly warped groin. We have studied 


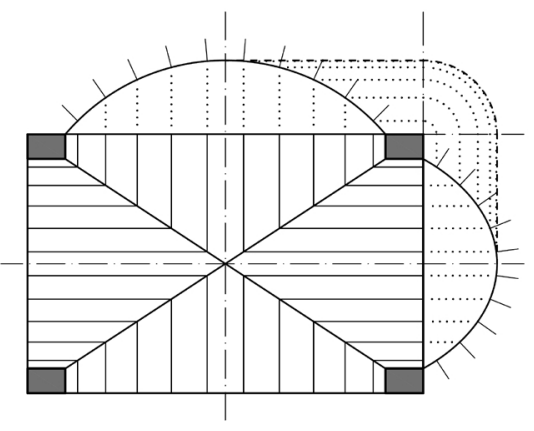

$4 \mathrm{a}$

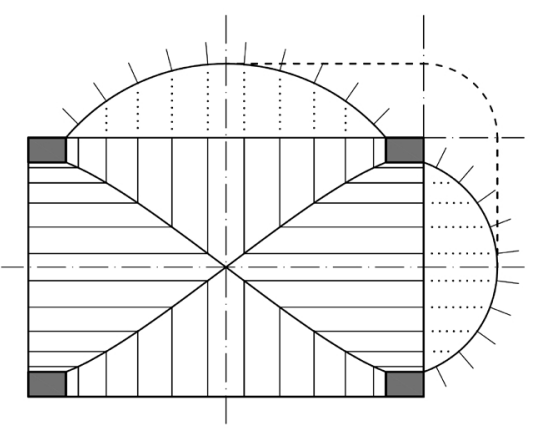

$4 \mathrm{~b}$

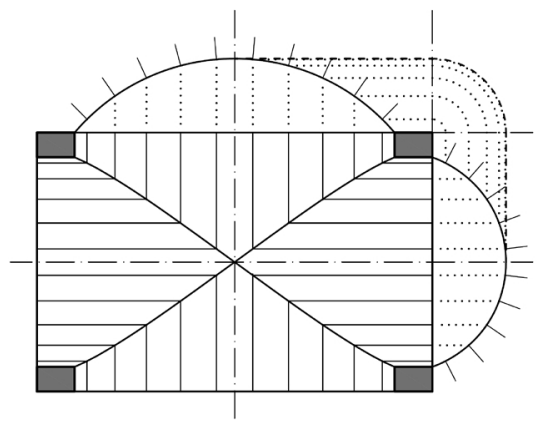

4C

de ellas es evidente el alabeo de la arista Hemos estudiado once de estas bóvedas de arista, construidas entre los siglos XVII y XVIII, analizando el proceso de construcción geométrica de la forma de la bóveda y su relación con las soluciones descritas por Gelabert. $^{2}$

El análisis de estas bóvedas se ha llevado a partir de un levantamiento tridimensional de las mismas. La toma de datos para los

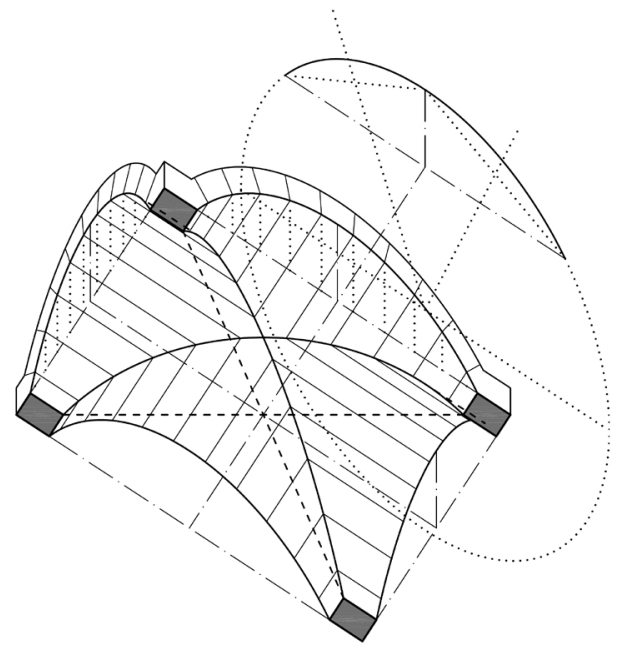

4. Interpretación gráfica de los tres trazados recogidos en el manuscrito de Gelabert para la bóveda de arista rectangular.

4. Graphical explanation of the three constructions for the rectangular groin vault reflected in Gelabert's manuscript.
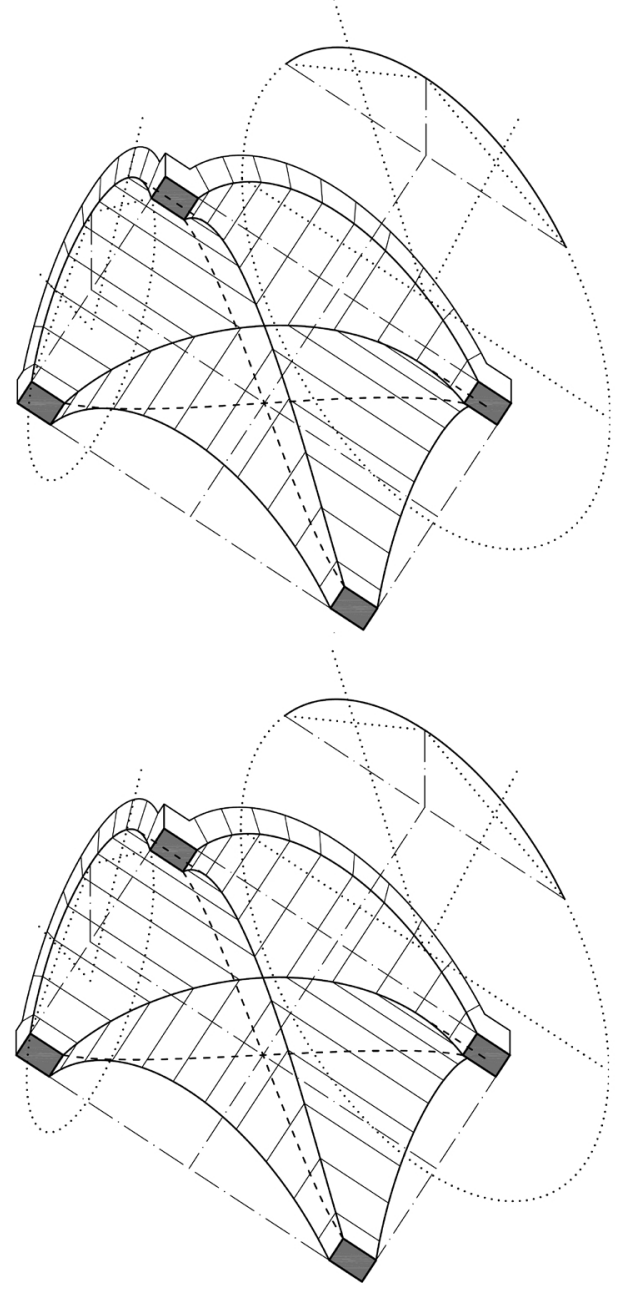

eleven of these vaults, built between the 17 th and 18th centuries, analyzing the geometrical construction of the form of the vault and its relationship with the solutions described by Gelabert. ${ }^{2}$

The analysis of these vaults has been based on their three-dimensional surveys. The data gathering was carried out with a laser total station for the first three buildings, and with digital photogrammetry with convergent
${ }^{2}$ Las bóvedas estudiadas han sido: una bóveda en la iglesia de Sant Francesc (s.XVI), una bóveda en el patio del Can Forteza del Sitjar (s.XVI-XVII), dos bóvedas en la recepción del Hotel Born (antiguo Can Ferrandell, 1723), dos bóvedas en el Casal Solleric (c.1750), una bóveda en el Consulado del Mar (s. XVII), tres bóvedas yuxtapuestas en el patio de Can Vivot (1725), y una bóveda en un paso elevado sobre el carrer de Can Serra (Can Fontirroig, s.XVIII-XIX).

2 The analyzed vaults are: one vault in Sant Francesc church (s.XVI), one vault in the courtyard of Can Forteza del Sitjar (s.XVI-XVII), two vaults in the reception of Hotel Born (former Can Ferrandell, 1723), two vaults in Casal Solleric (c.1750), one vault in the Consulado del Mar (s.XVII), three juxtaposed vaults in the courtyard of Can Vivot (1725), and one vault on an overpass on carrer de Can Serra (Can Fontirroig, s. XVIII-XIX) 
levantamientos se ha realizado por medio de una estación total equipada con distanciómetro láser en los cuatro primeros edificios, y con fotogrametría digital de imágenes cruzadas en los restantes. En ambos casos, la toma de datos ha consistido en la toma de puntos singulares de la superficie de las bóvedas correspondientes a los arcos del perímetro, las aristas, las hiladas y las juntas, que ha permitido construir un modelo tridimensional de líneas para su posterior análisis.

Las bóvedas obtenidas siguiendo los distintos procedimientos descritos por Gelabert son muy parecidas entre sí y, al comparar unas con otras, las medidas difieren poco en valor absoluto. Por este motivo el análisis se ha centrado en los aspectos que caracterizan marcadamente la geometría de las tres soluciones: el trazado de la arista, la directriz de los arcos del perímetro, y a la anchura y disposición de las hiladas. Es necesario considerar además las deformaciones sufridas por la bóveda durante su construcción o posteriormente, y cómo afectan a las características antes señaladas, destacando aquellos aspectos que permanecen a pesar de la deformación. Se han medido, siempre que ha sido posible, los desplomes de los muros para poder valorar su efecto sobre la bóveda; en todas las bóvedas se ha medido un descenso de la clave.

El trazado de la arista en planta es la característica que resultaría más evidente a simple vista. En el primer trazado, la arista sería recta, mientras que el segundo y tercer trazado sería curva; circunstancia que no se vería afectada por un descenso de la clave. En el primer y tercer tipo la proyección vertical de la arista se superpondría con la del arco perimetral; en cambio, en el segundo tipo, la proyección de la arista no coincidiría con el arco perimetral de menor luz; sin embargo este aspecto sí sería alterado por un descenso de la clave, por lo que debe ser analizado con precaución. En cualquier caso, cuanto más se aproxime la proporción entre los lados del rectángulo al cuadrado, y cuanto más rebajada sea la bóveda, menos perceptible es la curvatura de la arista. Hemos estimado que para bóvedas poco rebajadas, con una flecha igual o superior a $1 / 3$ de la luz del lado menor del rectángulo, el alabeo de la arista en planta es perceptible (superior a 1/200 de la diagonal); para bóvedas muy rebajadas, con una flecha igual inferior a $1 / 6$ de la luz del lado menor, el alabeo de la arista no es apreciable.

Por lo que respecta a los arcos del perímetro, en la primera bóveda el arco menor images in the remaining vaults. In both cases the data gathering gave the coordinates of a certain number of strategically selected points on the surface of the vault, belonging to the perimeter arches, the groins, the courses and the joints, which allowed to construct a three-dimensional model for further analysis.

The vaults created by using the different procedures described by Gelabert are very similar to each other; when they are compared, the measures differ very little in absolute value. For this reason, the analysis has been focused on the features that noticeable characterize the geometry of the three solutions: the layout of the groin, the layout of the perimeter arches and the width and dispositions of the courses. It's also necessary to consider the deformation suffered by the vault during its construction or thereafter, as well as how this affects the aforementioned characteristics, while highlighting those aspects that remain despite the deformations. Whenever possible, the lean of the walls has been measured, in order to assess its effect on the vault; in all the analyzed vaults, a descent of the central keystone has been measured.

The profile of the groins is the most evident feature to the naked eye. In the first solution, the horizontal projection of the groin would be straight, whereas in the second and third solution it would be waved; this aspect wouldn't be affected by a descent of the keystone. In the first and third type of vault, the vertical projection of the groin would overlap with that of the perimeter arch; whereas in the second type, the vertical projection of the groin wouldn't meet the vertical projection of the narrower arch; yet this feature would be affected by the deformation of the vault, so it must be analyzed carefully. In any case, the closer the ratio between both sides of the rectangle is to $1: 1$ (square plan), and the more lowered the vault is, the less noticeable the curvature of the groin will be. We have estimated that, for slightly lowered vaults, with a sagitta equal or greater than 1/3 of the span of the narrower side of the rectangle, the waving of the groin is noticeable (greater than $1 / 200$ of the diagonal); for very lowered vaults, with a sagitta equal or smaller than 1/6 of the span of the narrower side, the waving of the groin is not noticeable.

With regard to the perimeter arches, the narrower arch in the first vault would have variable curvature, with the rest of the arches being circular arcs. If the arches are part of the wall, it's unlikely that they will have been deformed. 
tendría curvatura variable, mientras que el resto de las soluciones estaríamos ante un arco de circunferencia. Si los arcos están embebidos en un muro es poco probable que hayan sufrido variaciones en su forma.

En cuanto a la anchura y disposición de las hiladas, en el segundo tipo la anchura debería ser constante en los arcos perimetrales, aunque distinta para cada arco; en el primer y tercer tipo, la anchura de las dovelas sería constante en el arco mayor pero en el arco menor decrecería ligeramente al aproximarnos a la clave. Si el trazado partiera del arco menor, en lugar del mayor, la anchura de las hiladas en el lado menor sería constante y en el arco mayor crecería ligeramente al aproximarse a la clave.

En algunos casos se han observado diferencias notables en la anchura de las dovelas en la coronación del arco (clave y contraclaves), lo que hace pensar en un posible ajuste. ${ }^{3}$ La horizontalidad o inclinación de las hiladas también depende de la solución, ${ }^{4}$ pero esta característica es muy sensible a las deformaciones de la bóveda.

A partir de la toma de datos, y teniendo en cuenta las consideraciones anteriores, ha sido posible establecer la relación entre cada una de las bóvedas analizadas (a excepción de la bóveda de Sant Francesc ${ }^{5}$ ) con alguna de las soluciones propuestas en el manuscrito.

La bóveda en el carrer de Can Serra (Figura 5) es el único ejemplo de los analizados que corresponde al primer tipo descrito por Gelabert. Se trata de una bóveda de proporción $3: 2$, muy rebajada, en la que los arcos de mayor luz tienen curvatura variable, obtenida igualando las alturas de las hiladas. Al ser una bóveda muy rebajada, el hecho de no apreciar el alabeo de la arista en el levantamiento no puede considerarse concluyente, por lo que el análisis se ha centrado en los arcos del perímetro

El segundo tipo queda representado por una de las bóvedas del Casal Solleric (bóveda de la entrada) y la bóveda del Consulado del Mar (Figura 6).

En el Casal Solleric el alabeo de la arista es evidente, los arcos perimetrales son arcos de circunferencia y están divididos en partes iguales a partir de la segunda hilada. La bóveda del Consulado del Mar una curvatura distinta en los arranques (tres primeras hiladas), a partir de la cuarta hilada los arcos se dividen también en partes iguales.
Regarding the width and disposition of the courses, in the second type the width of the courses of the perimeter arches would be constant, thought different for each arch; in the first and third type of vault, the width of the courses would be constant for the larger vault, but in the smaller vault they would slightly decrease when approaching the keystone. If the design begins with the narrower arch, instead of the wider one, the width of the courses in the smaller vault would be constant and they would widen when approaching the keystone in the larger vault.

In some cases, we have observed significant differences in the width of the groins at the summit of the arch (keystone and counterkeystones), which suggest a possible adjustment. ${ }^{3}$ The slope of the courses (horizontal or rising slope) depends on the solution, ${ }^{4}$ but this feature is very sensitive to the deformations of the vault.

From the data gathering, and mindful of the above considerations, it has been possible to establish the relationship between each of the analyzed vaults and the constructions described in the manuscript (except for the vault in Sant Francesc church ${ }^{5}$ ).

The vault in carrer de Can Serra (Figure 5) is the only example among the analyzed vaults corresponding to the first type described by Gelaber. The wider arches of this very lowered vault, with a proportion of $3: 2$, are arcs of variable curvature, obtained by ordinates (equaling the heights of the courses). Since this is a very lowered vault, not noticing the waving of the groins in the survey can't be conclusive, that's why the analysis has been focused in the perimeter arches.

The second type is represented by one of the vaults in Casal Soleric (vault at the entrance) and the vault in the Consulado del Mar (Figure 6).

In the Casal Solleric, the waving of the groin is clear, the perimeter arches are circumference arcs and they are divided in equal parts starting from the second course. The vault in the Consulado del Mar has a different curvature in the springs (three first courses), from the fourth course the arches are also divided in equal parts.

The vault in the Consulado del Mar has a particularity: the groin doesn't match the bend of the pieces of the enfourchement, but its position is forced to meet the diagonals of the rectangle.
${ }^{3}$ El único procedimiento que podían emplear los maestros canteros para dividir un arco en un número impar de partes iguales consistiría en hallar su longitud por medio de una cuerda y dividirla por Tales, pero parece poco probable su empleo. Si se hace por aproximación y se empieza la división por los arranques, la clave será la que absorba el error, lo que se corresponde con las observaciones realizadas.

${ }^{3}$ In order to divide the arch in an odd number of equal parts, stone masons could take its length by means of a rope and divide it using the "Intercept theorem", but its employment seems unlikely. If it was done by approximation, and they began the division in the springing, the keystone would have taken the error, which corresponds to our remarks.

${ }^{4}$ En la segunda solución descrita por Gelabert, las hiladas de la bóveda menor no son horizontales sino ligeramente ascendentes; en los restantes casos son horizontales.

${ }^{4}$ In Gelabert's second solution, the courses of the smaller vault are not horizontal but slightly upward; in the other cases they are horizontal.

${ }^{5}$ No ha sido posible sacar conclusiones sobre esta bóveda debido a las muchas irregularidades que presenta.

${ }^{5}$ It hasn't been possible to draw conclusions from this vault because of its many irregularities.

${ }^{6}$ Los tratados franceses emplean dos términos distintos para diferenciar la arista de intersección (arête) de las dovelas que la construyen (enfourchement), distinción que no hacen los tratados escritos en castellano pero que puede resultar útil. Un término en español que podría emplearse para distinguir el enfourchement es horcajadura u horcajo, con la misma raíz latina que el término francés: furca.

${ }^{6}$ French treatises use two different names to differentiate the curve of the groin (arête) from the pieces to construct it (enfourchement), this distinction is not made in Spanish but can be useful. A Spanish term that could be used to distinguish the enfourchement is horcajadura $u$ horcajo (fork), with the same Latin root as the French term: furca. 
5. Tipo 1: Bóveda del carrer de Can Serra.

5. First type: Vault in carrer de Can Serra.

6. Tipo 2: Bóveda del Casal Solleric.

6. Second type: Vault in Casal Solleric.
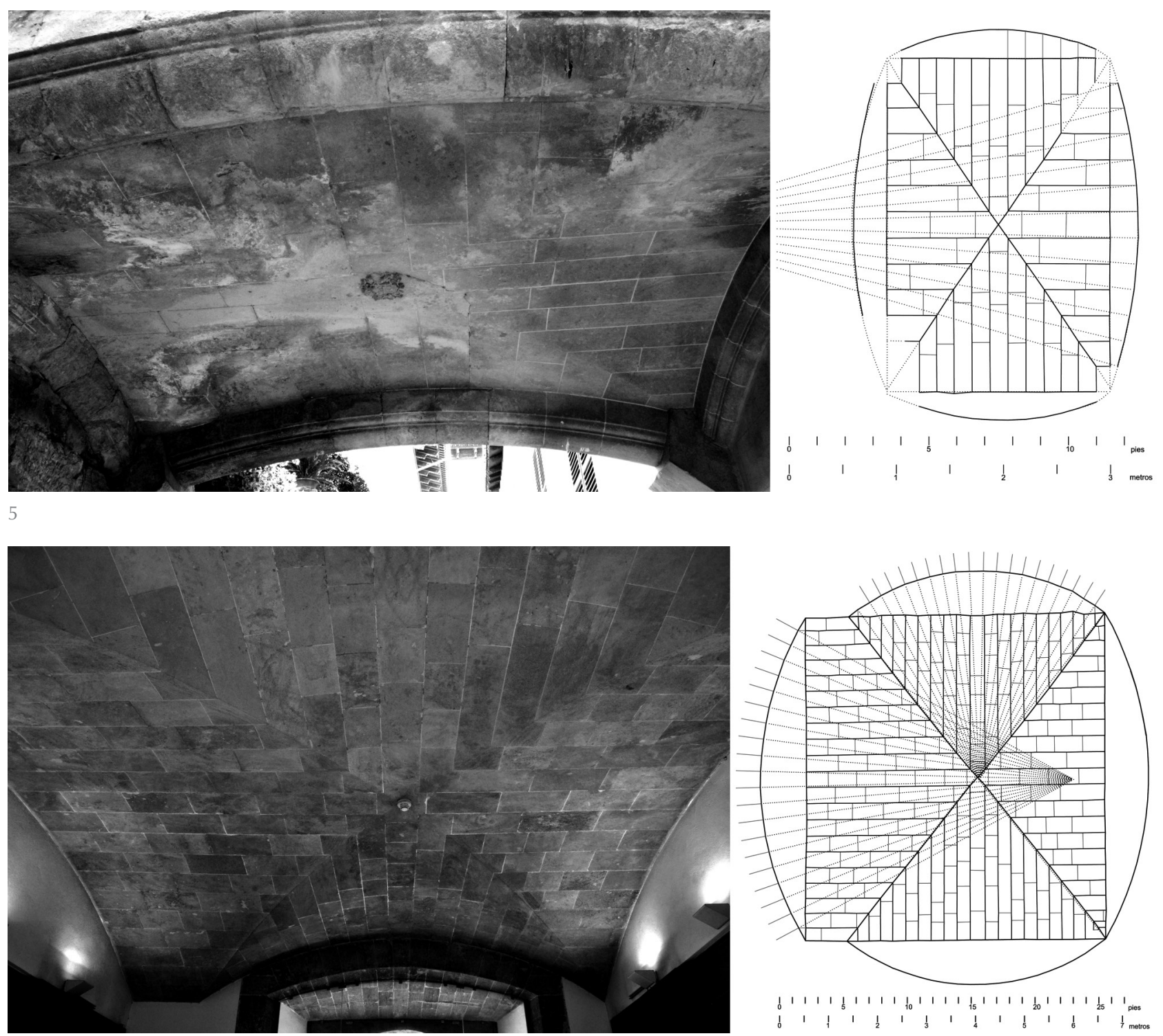

El alabeo de la arista podría suponer alguna dificultad a la hora de construir la cimbra.

ta una particularidad: la arista no coincide con el quiebro de las dovelas del enfourchement $^{6}$ sino que se fuerza su trazado para que corresponda con las diagonales del rectángulo.

Por su parte, las bóvedas de Can Forteza del Sitjar, de Can Vivot, del Hotel Born (Figura 7) y la de la esquina sur del patio del casal Solleric corresponden con el tercer tipo, inventado por Gelabert. En todos estos casos el alabeo de la arista es evidente y los arcos del perímetro son arcos de circunferencia. El trazado se realiza igualando alturas en los arcos del perímetro de modo que las hiladas son horizontales aunque no de ancho constante. the reference of the groin pieces it would be possible to build the second barrel vault without centering all its surface (Figure 8),
On the other hand, the vaults in Can (Figure 7) and the one at the southern corner of the courtyard in Casal Solleric correspond to the third type: Gelabert's invention. In all these examples, the warping of the groin is noticeable and the design is performed by equaling the heights of the courses in the perimeter arches so the courses are horizontal but with non-

The warping of the groin could pose some difficulties for the building of the centering. A relatively simple solution could be to build the centering of one of the barrel vaults, that will support its voussoirs; with 

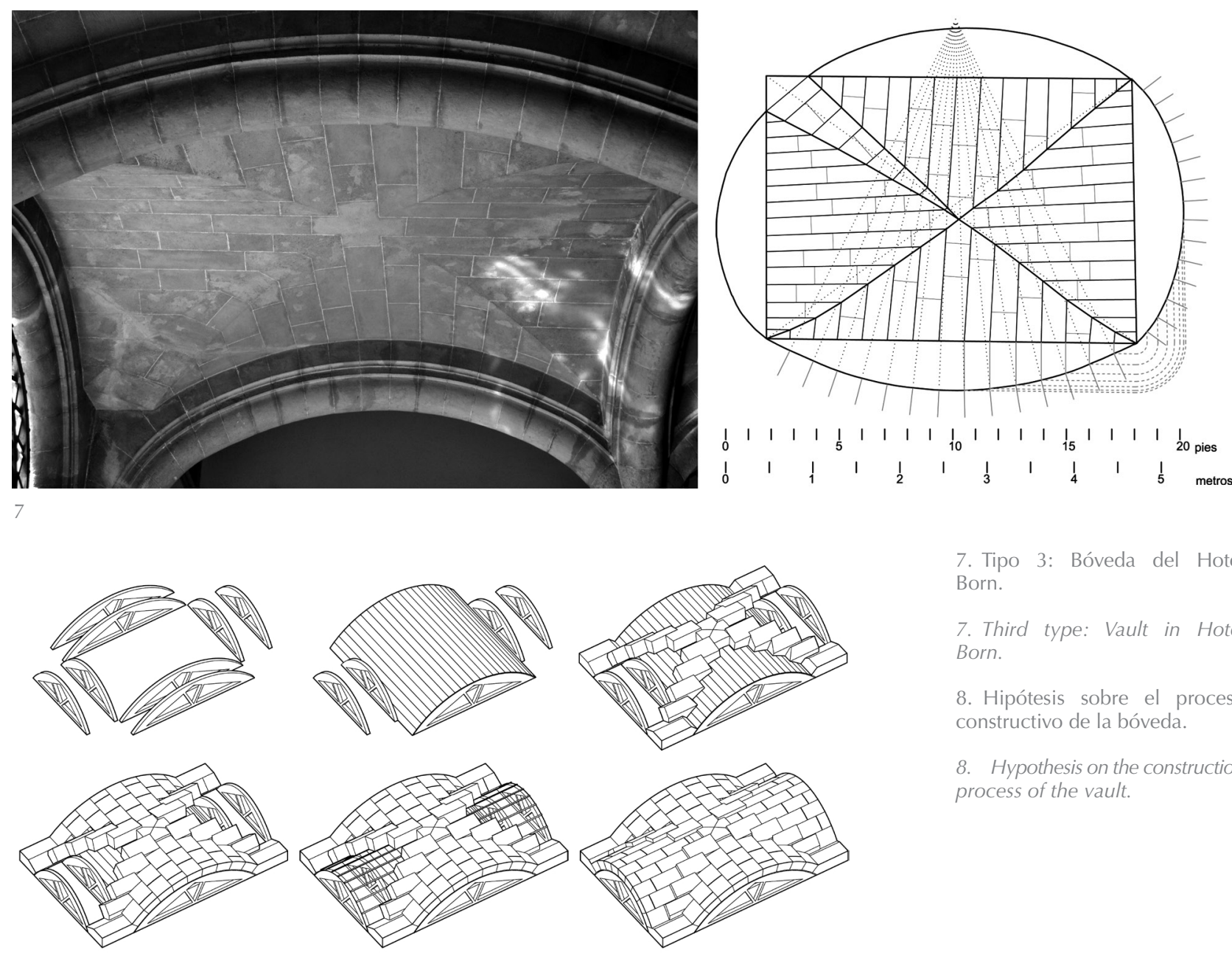

8

Una solución relativamente sencilla sería construir la cimbra de una de las bóvedas, sobre la que se apoyarían las dovelas de dicha bóveda; tomando como referencia las piezas de la arista sería posible construir la segunda bóveda sin necesidad de cimbrar toda su superficie (Figura 8), en una solución similar a la descrita por Choisy para el puente de Sangarius (s.VI) (6, pp. 27-28). Gelabert no da ninguna indicación al respecto.

\section{TALLA DE LAS PIEZAS DE ARISTA MEDIANTE PLANTILLAS DE INTRADÓS}

A pesar de que el método normalmente utilizado para la talla de las aristas de una bóveda de este tipo es el conocido como de los robos o escuadría, a partir del siglo XVII se empezaron a desarrollar métodos de taIla basados en el uso de las plantillas de intradós de las pieza de arista y el ángulo que forman sus caras. En Francia se abordó la búsqueda de dicho ángulo, en el Ilamado ángulo sólido, ${ }^{7}$ desde un punto de vista intelectual, geométrico y abstracto. Se hacía necesario para el desarrollo de cualquier in a similar solution to that described by Choisy for the Sangarius pont (s.VI) (6, pp. 27-28). Gelabert gives no indication on this issue.

\section{CARVING THE GROIN PIECES BY MEANS OF TEMPLATES}

Although the usual method to carve the pieces of the groin in this kind of vault is known as squaring, from the 17th century onwards other methods were developed based on the use of templates of the intrados surfaces and the angle between these surfaces. In France the search of this angle, in a solid angle, ${ }^{7}$ was addressed from an intellectual, geometrical and abstract point of view. It was necessary in order to develop any vault defined by groins, as it allowed carving the pieces from the intrados surface with the direct carving method (also known as templates carving method). While the squaring method implies the carving of the pieces twice, the first one to square the block and the second one to carve the piece itself, the stonemason who handles the intrados templates and the angle between surfaces, dresses one of the faces and, as he knows
7. Tipo 3: Bóveda del Hotel Born.

7. Third type: Vault in Hotel Born.

8. Hipótesis sobre el proceso constructivo de la bóveda.

8. Hypothesis on the construction process of the vault.

\footnotetext{
Florimond de Beaune da ese nombre al ángulo que forman las caras de un diedro en su Doctrine de l'Angle Solide. El matemático francés redacta la proposición 16 explicando cómo obtener el ángulo diedro de un triedro representado en proyección horizontal gracias a la ayuda de un plano auxiliar.

Florimond de Beaune gives this name to a trihedral and the study of the angles formed by the faces in his Doctrine de I'Angle Solide. The French mathematician poses the Proposition 16 explaining how to obtain the dihedral angle of a trihedral represented in horizontal projection by means of an auxiliary plane.
} 
${ }^{8}$ En el tratado se dibujan para la bóveda de arista cuadrada y rectangular. En una copia que se encuentra en Játiva aparecen dibujadas las plantillas de intradós de la bóveda de arista de planta triangular, pentagonal y romboidal. Las tres aparecen en el tratado original, pero sin desarrollar sus plantillas de intradós.

${ }^{8}$ In the treatise, the templates are drawn for the square and rectangular vaults. In a copy preserved in Xátiva the intrados templates of the triangular, pentagonal and rhomboidal groin vaults are also drawn. These three vaults appear in the original treatise, but without the construction of the intrados templates.

${ }^{9}$ Tras una revisión del trabajo de Pérez de los Ríos y Alías (9), donde proponen otro procedimiento que supone la construcción de una maqueta de la bóveda para medir el ángulo de intradós, estimamos más oportuna la solución presentada en este artículo.

${ }^{9}$ After a review of the work by Perez and Alías (9), where they propose another carving method that involves the construction of a model of the vault in order to measure the intrados angle, we estimate that the solution exposed in this article is more accurate.

10 En la revisión crítica del manuscrito de Gelabert, Rabasa explica el proceso de labra de una pieza de la bóveda de arista cuadrada, acompañándolo con un dibujo de los pasos a seguir en la talla (5, p. 141). Dicha imagen ha sido utilizada en la Figura 9.

10 In the scholarship edition of Gelabert's manuscript, Rabasa explains the carving process of a piece of the square groin vault, with a design explaining the steps $(5$, p. 141). This design has been used in Figure 9. bóveda definida por aristas, pues permitía acometer la labra de las piezas a través de las caras de intradós mediante el método directo de talla. Mientras que el método de los robos requiere realizar dos tallas en la piedra, una para escuadrar el bloque y otra para terminar de labrar la pieza, el cantero que maneja las plantillas de intradós y el ángulo que forman, labra una de las caras $y$, al conocer el ángulo que forma con la contigua, la talla de esta última es inmediata. Lo único que se debe prever es el tamaño de la piedra para contener la pieza buscada. Por lo tanto, este procedimiento de labra permite economizar material y tiempo (7, pp. 152-160).

Las primeras indicaciones para trazar las plantillas de intradós de las piezas de arista las encontramos en Le Secret d'Architecture en $1642 .^{8}$ Son probablemente fruto de la temprana intuición de su autor, Mathurin Jousse (8, pp. 156-163), que es capaz de dibujarlas pero no de explicar cómo han de utilizarse ni del modo de obtener el ángulo que forman las caras de intradós. La única posibilidad de hacer uso de estas plantillas en la talla es trasladando a la piedra el ángulo que forma la primera cara que se traza en la pieza con el plano horizontal. Para ello se puede utilizar una saltarregla colocada perpendicularmente a las líneas horizontales de la plantilla, marcando la recta que pasa por la esquina inferior de la arista. Apoyándose en esta recta y en la arista se obtiene la otra cara de la pieza. Se coloca la otra plantilla ajustándose a la diagonal y se retira la piedra sobrante. El trabajo finaliza con la talla de las concavidades de intradós y los lechos mediante el uso del baivel $^{9}$ (Figura 9a).

Once años después, Gelabert (1653) recoge en su manuscrito la construcción de unas ingeniosas plantillas de intradós para la talla de las piezas de arista de bóvedas de arista de planta cuadrada y rectangular, que nada tienen que ver con las propuestas por Jousse. Gelabert no es ni un geómetra ni un intelectual, sino un cantero y constructor de bóvedas que recoge en su tratado sus conocimientos del oficio. Explica cómo obtener una especie de plantillas espaciales a partir de la planta de la bóveda que, colocadas sobre una cara y dobladas sobre la cara contigua perpendicular a la anterior, permiten llegar a definir y tallar los planos de intradós de la pieza. ${ }^{10}$ Gelabert no calcula gráficamente el ángulo que forman las caras de intradós, pero con las plantillas se determina sin ningún problema (Figura 9b). En el caso de las bóvedas rectangulares, el alabeo de la arista se obtiene directamente de la labra de las dovelas por medio de este procedimiento. the angle between this face and its adjacent, carves this second face immediately. The only thing to foresee is the size of the block containing the resulting piece. Therefore, this carving procedure allows saving time and material (7, pp. 152-160).

The first instructions to design the intrados templates of the pieces of the groin can be found in Le Secret d'Architecture published in $1642 .{ }^{8}$ These templates are probably the result of an early intuition of the author, Mathurin Jousse (8, pp.156-163), who is able to draw them, but doesn't give any explanation about the way to use them, or the way to obtain the angle between the intrados faces of the piece. The only way to use these templates for carving the groin pieces is by transferring to the stone block the angle between the first face to be dressed and the horizontal plane. In order to do this, you can use a fausse équerre or sauterelle placed perpendicularly to the horizontal lines of the template, to mark the straight line that passes through the bottom edge of the groin. Relying on this line and on the groin, the other face of the piece can be obtained. The other template is placed fit to the diagonal and the excess of stone is removed. The work is concluded by dressing the concavity of the intrados and the beds using a bevel ${ }^{9}$ (Figure 9a).

Eleven years later, Gelabert (1653) described in his manuscript the construction of some very ingenious intrados templates to carve the groin pieces of a square groin vault and a rectangular groin vault, which has nothing to do with the templates proposed by Jousse. Gelabert was neither a geometer nor an intellectual, but a stonemason and a vault builder who collected in his treatise his practical knowledge of the profession. He explains how to obtain a sort of spatial template from the horizontal projection of the vault that, placed over a face of the stone and perpendicularly folded over the adjacent face, allows to define and carve the intrados surfaces of the vault. ${ }^{10}$ Gelabert doesn't graphically calculate the angle between the intrados surfaces, but with his templates the angle is easily found (Figure $9 b)$. For the rectangular vaults, the warping of the groin is directly obtained from the carving of the pieces by means of this procedure.

In the stonecutting workshop at the School of Architecture in Madrid we are carrying on the carving of a square groin vault using Gelabert's method. Thanks to the advice of the stonemason César Cabeza we have seen that the most effective and fastest procedure to dress the pieces of the groins is to rely on two straight lines, what 
En el Taller de cantería de la Escuela Superior de Arquitectura de Madrid se está llevando a cabo la talla de una bóveda de arista de planta cuadrada mediante el método de Gelabert. Gracias a las indicaciones del cantero César Cabeza hemos podido comprobar cómo, la manera más eficaz y rápida de tallar el plano que forman las aristas, es apoyándose en dos rectas, lo que el tratadista mallorquín llama picar a creuer $(5$, pp. 260 y 278$) .{ }^{11}$

La búsqueda del ángulo sólido y su aplicación seguirá generando interés en Francia, en especial tras la redacción entre 1639 y 1644 de la Proposición 16 en La Doctrine de I'Angle Solide de Florimond de Beaune (10, pp. 36-39), siendo fundamental la aportación de Philippe de La Hire a finales del siglo XVII, pues establece un método para determinar el ángulo sólido aplicado a la bóveda de arista rectangular. En la Proposición 13 del Tomo 1 del manuscrito Coupe de Pierres (11, Fols. 71r-74v), La Hire presenta el caso dibujando en el Fol. 73 las plantillas de intradós de las piezas de la arista y la construcción geométrica necesaria para obtener el ángulo diedro de la segunda pieza de la bóveda (12). Tras haber hallado este ángulo, se coloca una plantilla de intradós en una cara de la piedra y con una saltarregla se traslada la medida del ángulo sólido. Una vez labrada la cara contigua se coloca la otra plantilla de intradós. De este modo, lo único que faltaría por labrar son las concavidades de intradós y los lechos, que como bien indica La Hire en el siguiente folio, sólo necesitan una cercha curva (Figura 9c). the Majorcan author calls picar a creuer (5, pp. 260-278). ${ }^{11}$

The search of the solid angle and its applications would continue to create interest in France, especially after Proposition 16 of La Doctrine de I'Angle Solide by Florimond the Beaune (10, pp. 36-39), written between 1639 and 1644; here the contribution by Philippe de La Hire in late 17th century is essential, as he establishes a method to determinate the solid angle applied to the rectangular groin vault. In Proposition 13 of the First Volume of his manuscript Coupe des Pierres $(11$, Fols. $71 r-74 v)$, La Hire exposes the construction of the groin vault; in Fol. 73 he draws the intrados templates of the groin pieces and the geometric construction to calculate the dihedral angle of the second piece of the vault (12). After having found this angle, an intrados template has to be placed on one of the faces of the stone and, with a sauterelle the angle between faces can be transferred. Once the adjacent face has been carved its intrados template can be placed. Thus, the only thing missing to be dressed are the concavities of the intrados and the beds, which can be made by means of a curved ruler, as La Hire indicates on the following page.

However, the geometrical problem of obtaining the angle between the faces of a dihedral was already found by the Spanish architect Hernán Ruiz the Younger in his Libro de arquitectura (c. 1560) although not applied to the groin vault, as the previous authors, but to a pyramid (13, Fol. 25v).
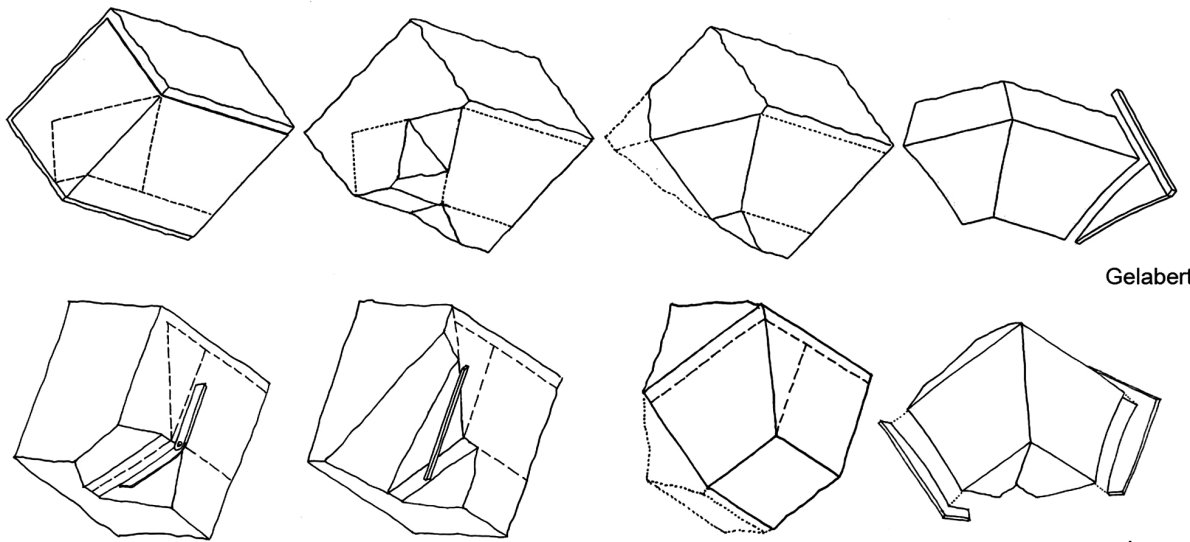

Gelabert
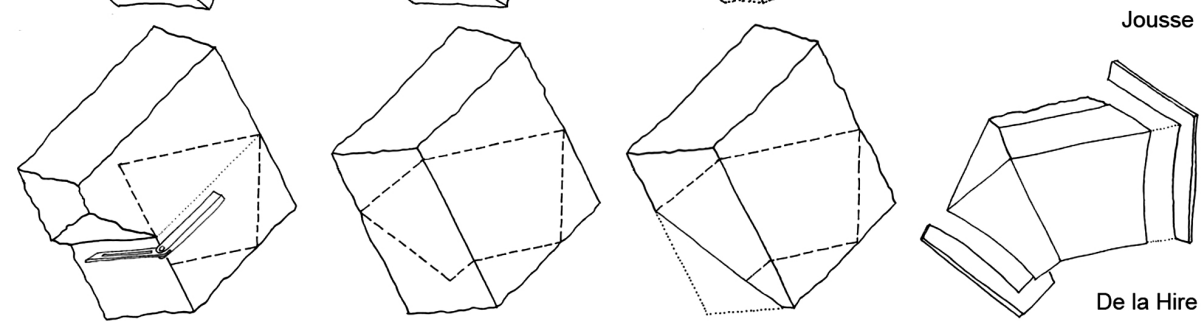

9. Proceso de talla de una pieza de la bóveda de arista según Gelabert, Jousse y La Hire.

9. Carving process of a groin piece according to Gelabert, Jousse and La Hire.

\footnotetext{
${ }^{11}$ En la nota 351 Rabasa explica que picar a creuer es labrar o tallar a la cruz, es decir "desalabeando o definiendo el plano a partir de dos rectas que se cortan". Véase también la nota 58 en la página 78.
}

11 In footnote 351 Rabasa explains that picar a creuer is tallar a la cruz, that is to say, "un-warping or defining the plane from two intersecting lines". See also footnote 58 on page 78 . 
10. Libro de arquitectura de Hernán Ruiz el Joven, Fol. 25v e interpretación.

10. Libro de arquitectura by Hernán Ruiz the Younger, Fol. $25 \mathrm{v}$ and interpretation
${ }^{12}$ En el original: "Esta figura aquí deseñada es para sacar la saltarregla para las esquinas o aristas deste pirámide, si a de ir guarneçido de alizares o de otra cosa semejante asentadas por cuadrado" (13, Fol. 25v).

12 In the original "This figure drawn here is to obtain the sauterelle for the corners or edges of this pyramid, if it has to be plastered with alizares or something similar, squarely settled" (13, Fol. 25v).

13 Hay que tener en cuenta que este punto coincide con el centro del cuadrado, no siendo así en el caso de elementos de planta rectangular.

${ }^{13}$ It should be noted that this points meets the center of the square; this is not so if the element has a rectangular plan.
Sin embargo, este problema geométrico de obtener el ángulo que forman las caras de un diedro ya lo había determinado gráficamente el arquitecto español Hernán Ruiz el Joven en su Libro de Arquitectura (c. 1560), si bien es cierto que no aplicado a una bóveda de arista, como los autores antes mencionados, sino a una pirámide (13, Fol. 25v). En el Fol. 25v presenta una figura diseñada para sacar la saltarregla para las esquinas o aristas de una pirámide que ha de ir guarnecida de alizares (azulejos de borde) o de otra clase semejante asentados por cuadrado (14, pp.206-207). Lo que pretende Hernán Ruiz es encontrar el ángulo que forman las dos caras inclinadas de la pirámide para poder así realizar unos azulejos en "L" con ese ángulo que se dispongan en la arista y evitar realizar una junta (Figura 10). Esta intención queda dibujada en la proyección vertical del dibujo, en la que representa un rectángulo que debe ser un azulejo y la posición que se quiere que tome, con dos rectas perpendiculares a la proyección de la diagonal. ${ }^{12}$

La solución está en el abatimiento de la diagonal en la proyección vertical y en el punto $A^{\prime}$ que viene marcado en el dibujo original en la línea de tierra sin la presencia de ninguna línea auxiliar que nos indique su procedencia. Creemos que ese punto corresponde al abatimiento de la recta perpendicular a la diagonal con origen en el centro del cuadrado en planta. ${ }^{13}$ De este
In Fol. 25v he draws a figure designed to find the sauterelle for the corners or edges of a pyramid that has to be plastered with alizares (edge tiles), or something similar, squarely settled (14, pp. 206-207). What Hernán Ruiz wants is to find the angle between the sloped faces of a pyramid in order to make " $L$ " shaped tiles with that angle, to be placed in the corner, thus avoiding making a joint (Figure 10). This intention is drawn in the upper side of the design, where he represents a rectangle, that must be the tile, and the arrangement he wants it to be, with two perpendicular lines to the vertical projection of the diagonal. ${ }^{12}$

The solution can be found by folding the diagonal edge in vertical projection, and rely on the point $A^{\prime \prime}$ that is marked on the original design in the horizontal line without any other auxiliary line showing its origin. We believe that this point corresponds to the rotation of a straight line, perpendicular to the diagonal, with its origin in the center of the square plan. ${ }^{13}$ Thus, it is easy to locate its projection $A^{\prime \prime}$ on the horizontal projection of the pyramid. The solid angle is defined by the lines $B A^{\prime \prime}$ and $A^{\prime \prime} C$.
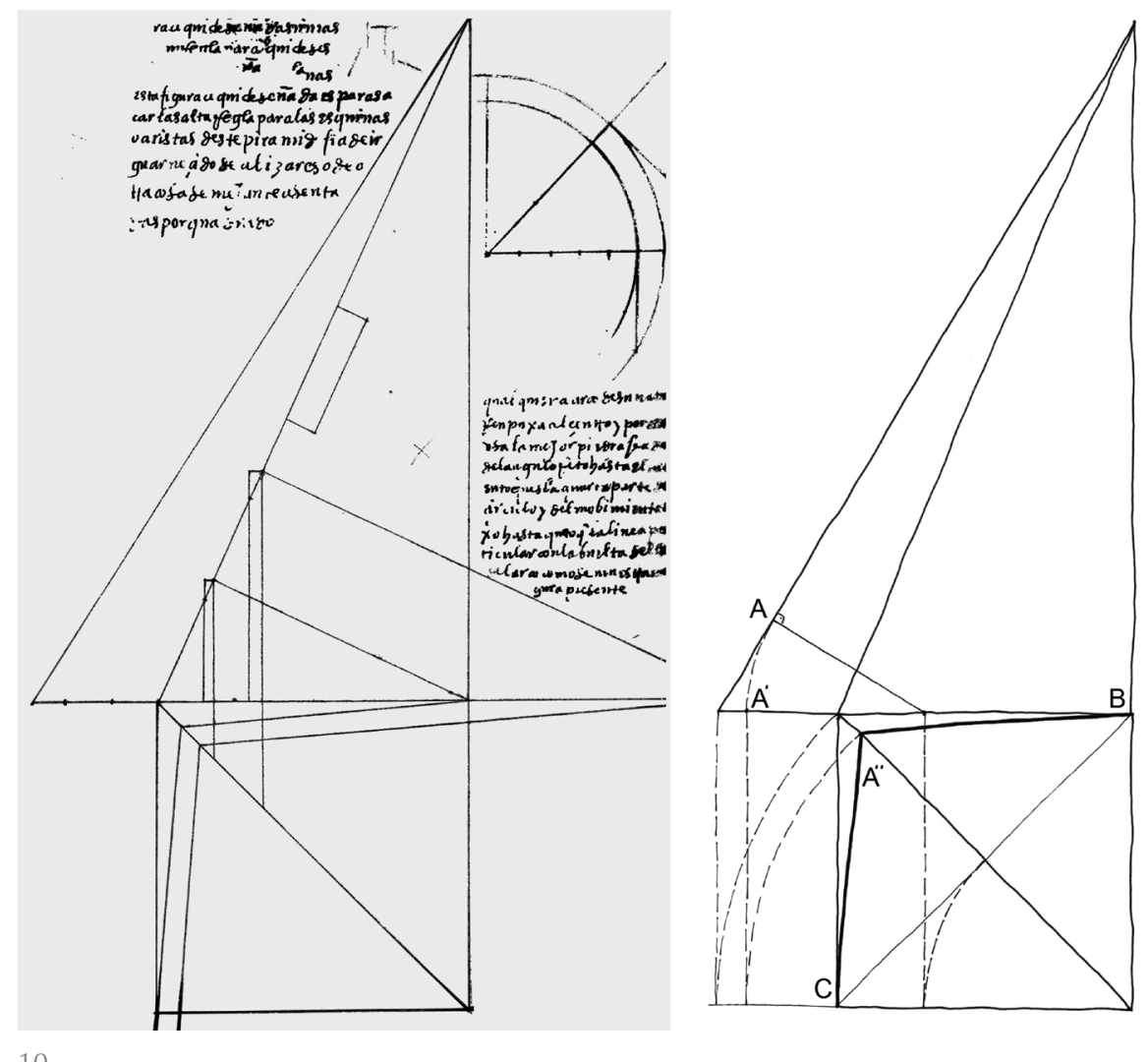
modo, es sencillo localizar su proyección A" en la planta de la pirámide. El ángulo sólido es el definido por las rectas BA" y $\mathrm{A}^{\prime \prime} \mathrm{C}$.

\section{CONCLUSIONES}

El manuscrito de Gelabert representa un caso singular en la forma de abordar el problema de la bóveda de arista rectangular. No sólo es el único tratadista que propone tres soluciones distintas y contempla la posibilidad de que la arista sea una curva alabeada, además es el único que recurre a arcos rebajados, en lugar de emplear los habituales arcos de medio punto, seguramente reflejando una tradición constructiva anterior. Esto último ofrece interesantes posibilidades, ya que al suprimir la condición de tangente vertical en los arranques permite independizar la altura de la bóveda de su luz y pueden emplearse arcos de circunferencia de distinto radio, igualando la altura de las claves y situando el centro donde sea necesario, lo que le evita utilizar arcos de curvatura variable.

Este abanico de soluciones no es un ejercicio meramente teórico, sino que, tal y como hemos podido comprobar en las bóvedas analizadas, se trata de soluciones efectivamente llevadas a cabo en la práctica. A pesar de que la aparente dificultad de la arista alabeada podría hacer pensar en soluciones más teóricas que prácticas, el amplio número de casos en los que la arista se curva en el espacio permite afirmar que se trata de una práctica extendida. Tan sólo una de las bóvedas analizadas, la situada sobre el carrer de Can Serra, se resuelve por medio de una arista plana, lo que obliga a recurrir a arcos de curvatura variable; llama la atención comprobar que se trata de la bóveda más tardía.

De las bóvedas estudiadas, más de la mitad están emparentadas con la solución inventada con Gelabert y son posteriores al manuscrito, lo que apoya la posibilidad de que en efecto se trate de un procedimiento ideado por Gelabert.

En cualquier caso hay que tener presente que si bien es posible relacionar las bóvedas analizadas con las soluciones propuestas por Gelabert, esto se refiere a los principios generales de diseño; en la mayoría de los casos se observan irregularidades y ajustes que dependen de las condiciones concretas de cada bóveda. También hay que considerar la posibilidad de que existieran métodos alternativos de diseño, no contemplados por Gelabert, que también dieran lugar a aristas alabeadas.

\section{CONCLUSIONS}

Gelabert's manuscript represents a singular case in the way it addresses the problem of the rectangular groin vault. Not only is it the only treatise to propose three different solutions but it considers the possibility that the groin is a warped curve. Moreover, he is the only author to use lowered arches instead of semi-circular arches, probably reflecting a previous building tradition. This offers interesting possibilities as, abolishing the vertical tangent condition for the springing, the height of the vault is independent from its span and circular arches of different radii can be used, equaling the height of the keystone and placing the centers where required, which avoids using variable curvature arcs.

This range of possibilities is not a purely academic exercise, but, as we have seen in the analyzed vaults, these are solutions actually put into practice. Despite the apparent difficulty of the warped groin, which might suggest more theoretical than practical solutions, the large number of cases in which the groin is warped allows us to say that is a widespread practice. Only one of the analyzed vaults, the one in carrer de Can Serra, is solved with a plane groin that involves the use of variable curvature arcs; it draws our attention that this is the later vault.

Among the analyzed vaults, more than a half are related to the solution invented by Gelabert and were built after the manuscript was written, which supports the possibility that the third solution was in fact invented by Gelabert.

Anyway, we must keep in mind that although it's possible to relate the analyzed vaults to the solutions proposed by Gelabert, this refers only to the general principles of design; in most cases there are irregularities and adjustments that depended on the specific conditions of each vault. We must also consider the possible existence of alternative design methods, not considered by Gelabert, that also resulted in warped groins.

Comparing the carving method exposed by Gelabert, and what we now assume to be Jousse's method, the differences are obvious. The first one allows to control the volume of stone required very intuitively, marking the whole template in the very beginning of the process, which involves material saving. Moreover, there is no need to transfer any angle with auxiliary tools, which makes the carving procedure more immediate and quick. 
Comparando la labra de una pieza mediante el procedimiento presentado por Gelabert y lo que suponemos como método de Jousse, las diferencias son manifiestas. El primero permite prever de modo muy intuitivo el volumen de piedra aproximado que se necesitará en la talla, marcando desde un primer momento toda la plantilla; lo que conlleva ahorro de material. Además, no necesita trasladar ningún ángulo mediante instrumentos auxiliares, lo que hace que la talla sea más inmediata y rápida.

El método de La Hire posee la ventaja de permitir tallar cada pieza de modo independiente, siendo el proceso de labra rápido y eficaz. Sin embargo, el cantero debe tener presente que la pieza esperada esté contenida en el bloque de piedra elegido, pues no es sencillo preverlo a simple vista.

La particularidad del trazado de Hernán Ruiz radica en que resuelve gráficamente el problema geométrico del "ángulo sólido", un siglo antes del manuscrito de Florimond de Beaune, empleando un procedimiento que no volveremos a encontrar hasta el tratado de La Hire, a finales del s.XVII. Discrepamos de la interpretación que F. S. Pinto Puerto da de este dibujo, que lo describe como una "receta práctica" (14, pp. 206207).

En las bóvedas construidas, al observar las piezas del enfourchement, que tienen forma de "L", hemos comprobado cómo las piezas se sitúan sistemáticamente en la misma dirección y no se contrapean, como cabría esperar de una "buena práctica constructiva". Este hecho podría estar relacionado con el método de labra de las piezas de la arista por medio de plantillas, que obliga a tomar determinadas medidas de cada arco; si las piezas se disponen siempre según la misma dirección, las medidas se toman del mismo modo para todas las piezas lo que reduce las posibilidades de error. También podría estar relacionado con el sistema de cimbrado propuesto en el apartado 3, disponiendo la rama larga sobre la cimbra, para un mejor asiento.

\section{AGRADECIMIENTOS}

Este trabajo forma parte del Proyecto de Investigación "Construcción en piedra de cantería en los ámbitos mediterráneo y atlántico. Análisis de ejemplos construidos" (BIA2009-14350-C02-01) del Plan Nacional de I+D+i del Ministerio de Ciencia e Innovación. Las autoras quieren expresar su agradecimiento a las personas que les han permitido realizar la toma de datos de las bóvedas.
La Hire's method has the advantage of allowing the carving of each piece independently, the carving method being quick and efficient. However, the stone mason should foresee whether the piece is contained in the chosen stone block, as this is not easy to see with the naked eye.

The particularity of Hernan Ruiz's design lies in the fact that he solves graphically the geometric problem of the "solid angle", a century before Folrimond de Beaune's manuscript, using a procedure which wouldn't be used again until La Hire's treatise, at the end of the 17th century. We don't agree with F.S. Pinto Puerto's interpretation of this design that is described as a "practical receipt" (14, pp. 206-207).

In the built examples, we have noticed that the pieces of the enfourchement, which have an " $L$ " shape, are placed systematically in the same direction; they don't alternate, as one could expect from a "good building practice". This could be related to the procedure of carving the pieces of the groin by means of templates, which involves taking certain measures from each arch; if the pieces are all arranged in the same direction, the measures are taken in the same way, which reduces the chances of error. It could also be related to the centering system proposed in section 3, having the long arm of the piece on the centering, for a better settling.

\section{ACKNOWLEDGEMENTS}

This work is part of a research project "Construcción en piedra de cantería en los ámbitos mediterráneo y atlántico. Análisis de ejemplos construidos" funded by the Ministry of Science and Innovation of Spain (BIA2009-14350-C02-01). The authors wish to express their gratitude to the people who have allowed them to carry out the survey of the vaults. 


\section{REFERENCIAS / REFERENCES}

(1) Vandelvira, A. de (c.1575-1591). Libro de traças de cortes de piedras. Manuscrito. Madrid. Biblioteca de la Escuela Técnica Superior de Arquitectura (Edición facsimilar y transcripción/ Facsimile edition and transcription: Barbé-Coquelin de Lisle, G. (1977) Tratado de arquitectura. Albacete. Caja Provincial de Ahorros).

(2) San Nicolás, F. L. de (1639). Arte y uso de arquitectura. Primera parte. Madrid. Imprenta de Juan Sánchez (Edición facsimilar/Facsimile edition: Madrid. Albatros. 1989).

(3) Derand, P. F. (1643). L'Architecture des voutes ou l'art des traits et coupe des voutes. París, Sébastien Cramoisy.

(4) Gelabert, J. (1653). Verdaderes traces de l'art de picapedrer. Manuscrito. Palma de Mallorca. Biblioteca del Consell Insular de Mallorca (Edición facsimilar/Facsimile edition: Palma. Instituto de Estudios Baleáricos. 1977; trascripción, traducción y edición crítica/transcription, translation and commented edition: Rabasa Díaz, E. (2011) El manuscrito de cantería de Joseph Gelabert. Madrid. Fundación Juanelo Turriano).

(5) Rabasa Díaz, E. (2011). El manuscrito de cantería de Joseph Gelabert. Madrid. Fundación Juanelo Turriano.

(6) Choisy, A. (1883). L'art de bâtir chez les byzantins. París. Librairie de la Société Anonyme de Publications Périodiques (Traducción al castellano/Spanish edition: El arte de construir en Bizancio. Madrid. Instituto Juan de Herrera. 1997).

(7) Rabasa Díaz, E (2000). Forma y construcción en piedra. De la cantería medieval a la estereotomía del siglo XIX. Madrid. Akal.

(8) Jousse, M. (1642). Le secret d'architecture découvrant fidèlement les traits géométriques, couppes et dérobements nécessaires dans les bastimens. La Flèche. Georges Griveau.

(9) Pérez de los Ríos, C. y E. García Alías (2009). Mathurin Jousse: preludio de la estereotomía moderna. En Huerta, S. et al. (eds.) Actas del sexto Congreso Nacional de Historia de la Construcción (Valencia, 21-24 de octubre de 2009) (pp. 1041-1050). Madrid. Instituto Juan de Herrera.

(10) Beaune, F. de (c.1639-1644). La doctrine de L'Angle Solide construit sous trois angles plans. Manuscrito/manuscript. París. Académie des Sciences (Edición crítica/ Commented edition: P. Costabel. París. Librairie Philosophique J Vrin. 1975).

(11) La Hire, P. de. (1688-1690). La Coupe des Pierres, Tome I. Manuscrito/manuscript. París. École Nationale des Ponts et Chaussés.

(12) Tamborero, L. (2009). Les traites du trait, Les lires avec des outils. En Sakarovitch, J. (et al.) El arte de la piedra: Teoría y práctica de la Cantería (pp. 71-100). Madrid. CEU Ediciones.

(13) Ruiz el Joven, H. (c.1558-1562). Libro de Arquitectura. Manuscrito/manuscript. Madrid. Biblioteca de la Escuela Técnica Superior de Arquitectura (UPM).

(14) Pinto Puerto, F. S. (1998). El libro de cantería. En Jiménez, A. (et al.) Libro de Arquitectura. Hernán Ruiz II (pp. 199-214). Sevilla. Fundación Sevillana de Electricidad. 